\title{
Desulfurization of Crude Oil and Oil Products by Local Isolated Bacterial Strains
}

\author{
Ahmad F. Shahaby ${ }^{1,2^{*}}$ and Khaled. M. Essam El-din ${ }^{1}$ \\ ${ }^{1}$ Scientific Research Deanship, Biotechnology and Genetic Engineering Unit, \\ Taif University, Taif, Saudi Arabia \\ ${ }^{2}$ Department of Microbiology, College of Agriculture, Cairo University, Cairo, Egypt \\ *Corresponding author
}

\section{A B S T R A C T}

\begin{tabular}{|l|}
\hline Ke y w o r d s \\
Crude oil, Oil \\
products, \\
Dibenzothiophene, \\
Biodesulfurization, \\
Bacillus, \\
Pseudomonas, \\
Klebsiella, \\
Mycobacterium, \\
Rhodococcus, \\
16S-rRNA gene \\
\hline Article Info \\
\hline $\begin{array}{l}\text { Accepted: } \\
\text { 25 March } 2017 \\
\text { Available Online: } \\
\text { 10 April } 2017\end{array}$ \\
\hline
\end{tabular}

The presence of organic sulfur-containing oil in the environment is harmful to animals and human health. The combustion of these compounds in fossil fuels tends to release sulfur dioxide in the atmosphere, which leads to acid rain, corrosion, damage to crops, and an array of other problems. The process of biodesulfurization rationally exploits the ability of certain microorganisms in the removal of sulfur prior to fuel burning, without loss of calorific value. In this sense, we hypothesized that bacterial isolates from crude oil and oil products polluted soils can demonstrate the ability to degrade crude oil and oil products as well as dibenzothiophene (DBT), the major sulfur-containing compound present in fuels. The total sulfur bacteria were ranged from $1.6 \times 10^{4}-2.8 \times 10^{6} \mathrm{CFU} \mathrm{g}^{-1}$ soil $^{-1}$ on PCA media and $4.1 \times 10^{2}-2.1 \times 10^{6} \mathrm{CFU}_{\mathrm{g}}$ soil $^{-1}$ on basel media (BSM) supplemented with DBT. Those strains which showed great degradation efficiency in case of all investigated hydrocarbons were identified based upon the sequence analysis of their 16S- rRNA. Phenotypic and genotypic examination of the recovered isolates revealed that they belong to the five different genera of Bacillus, Pseudomonas, Rodococcus, Mycobacterium, and Klebsiella. All isolated bacteria showed to be capable of biodesulfurization of oil or oil products, as they were compared to standard strains (ATCC) and were able to grow in minimal mineral medium supplemented with DBT or $2 \mathrm{HBP}$ as the sole sulfur and carbon source. The potential application of these isolates for the biodesulfurization of oil and oil products as well as sulfur-containing compound in fuels prior to combustion was discussed. Furthermore, results indicated that using a microbial consortium might have a promising application in petroleum oil technology and could be potentially used in microbial enhanced oil recovery (MEOR).

\section{Introduction}

Sulfur is the most abundant element in petroleum after carbon and hydrogen. The average sulfur content varies from 0.03 to 7.89 mass\% in crude oil (Mehran et al., 2007). The sulfur compounds can be found in two forms: inorganic and organic. Inorganic sulfur, such as elemental sulfur, $\mathrm{H}_{2} \mathrm{~S}$ and pyrite can be present in dissolved or suspended form (Agarwal and Sharma 2010). Organic sulfur compounds such as thiols, sulfides, and thiophenic compounds represent the main source of sulfur found in crude oil. Crude oil and oil products have many components that have to be removed before 
they are usable in the marketplace. One of the most toxic elements in the crude products is sulfur. Sulfur forms compounds in oil and oil products, such as hydrogen sulfide, which are very corrosive and extremely toxic. Sulfur in gasoline is not only a source of air pollution, but also plays a significant role in determining the tailpipe emissions of other pollutants, such as nitrogen oxides, carbon monoxides and unburned hydrocarbons. Because of the boiling range, the composition of sulfur compounds in gasoline is unlike that found in diesel oil in which the main sulfur species are dibenzothiophene (DBT) and dibenzothiophenes with substitutions (Monticello, 1998). Mercaptans are a small portion of the gasoline sulfur compounds, whereas thiophene and alkylthiophenes make up the largest portion. Many refineries worldwide are using a variety of methods to reduce the concentration of sulfur in natural gas. Removing sulfur from fuel is becoming a more serious concern as crude oils are getting higher in sulfur content and regulated sulfur limits are becoming lower and lower (Holliger et al., 1997). To date, there is no common method for selective removal of sulfur from oil before its processing, which could be successfully applied on an industrial scale. Biodesulfurization is the application of microbial processes to convert organic sulfur compounds into harmless substances and removing of sulfur. The advantage of the study of biodesulfurization of crude oil is its cost-effectiveness when compared to some physicochemical techniques. Many microorganisms have been reported to use various petroleum hydrocarbons and sulfur compounds, as their sole carbon and energy substrate, despite their extreme insolubility in the aqueous phase. It is possible to desulfurize crude oil directly by selecting appropriate microbial species (Javadli, de Klerk. 2012). Numerous genera of bacteria are known as good hydrocarbon degraders Rhodococcus, Bacillus, Pseudomonas, Mycobacterium,
Klebsiella, Pseudomonas, Actinomycetes, Enterobacter and Acinetobacter (Izumi et al., 1994; Kirimura et al., 2000; Ishii et al., 2005; Al-Zahrani and Idris, 2010; Jamshid et al., 2010; Bhatia, Sharma, 2012; Buzanello et al., 2014); however, reports on the utilization of complex sulfur mixtures like crude oil by isolated microbial species are few. To obtain an efficient desulfurizing bacterial consortium and monocultures, knowledge of the diversity of the microbial community present in sites contaminated with crude oil, their metabolic features and capacity to desulfurize crude oil are of paramount importance. One of the factors that limit biodesulfurization of crude oil is their limited availability to microorganisms. Biodesulfurization has become an alternative way to remedy crude oil and refined products, where the addition of specific microorganism or enhancement of microorganism already present, can improve desulfurizing efficiency (Kvenvolden and Cooper, 2003). In order to develop environmental technologies for crude oil desulfurization, it is necessary to isolate and characterize specific microbial species for evaluation of their efficacy in utilization of sulfur compounds before application to crude oil. Information about efficiency of potential sulfur bacteria of contaminated soil with crude oil or oil refiners in Saudi Arabia is scant.

Bacterial communities are difficult to study due to their immense complexity and the potential problems in culture ability of many of the members (Abou-Shanab, 2007). Serological and bacteriological methods are not sensitive enough to differentiate all bacterial isolates (Taghi et al., 2008). Therefore, several molecular approaches now provide powerful adjuncts to the culturedependent techniques. Now Combination of colonial morphological, physiological, biochemical, serological and molecular markers is essential for successful 
identification either to the genus level or more frequently to the species level (Millar et al., 2007).

Bacterial 16S-rRNA is a common target for taxonomic purposes and identification, largely due to the mosaic composition of phylogenetically conserved and variable regions within the gene (Gurtler and Sanisich, 1996, Bayoumi et al., 2010).

This work represents a continuation of our research in the area of petroleum biodegradation technology. The study aims to characterize potential sulfur bacteria isolates from contaminated soil with crude oil or oil refiners. Api profiles as well as 16S-rRNA gene technique were employed for molecular characterization and identification of bacterial isolates. In addition, to describe the ability of selected bacterial strains to desulfurize crude oil and its refined products and to compare local isolated strains with reference commercial strains.

\section{Materials and Methods}

\section{Bacterial strains}

Local isolates and strains from previous work, laboratory collection and ATCC cultures were used in this research project.

\section{Isolation, identification and culture conditions}

Three grams of contaminated soil were added to sterile 250-ml Erlenmeyer flasks containing $50 \mathrm{ml}$ of Bushnell Hass Medium (BHM). The bacterial strain was isolated by repeated enrichment cultures adding crude oil or oil products as the source of carbon and energy. Each crude oil or oil products (crude oil, kerosene, benzene, motor oil, diesel oil and DBT) was supplemented at a final concentration of $200 \mathrm{mg} / \mathrm{l}$. The flasks were incubated in the dark on a rotary shaker at $30^{\circ} \mathrm{C}$ and $200 \mathrm{rpm}$ for 15 days. At the end of this period, the vials were allowed to settle for $1 \mathrm{hr}$. The supernatant of each vial was collected and re-suspended in phosphate buffer before being added into new 250-ml Erlenmeyer flasks containing $50 \mathrm{ml}$ BHM and $200 \mathrm{mg} / \mathrm{l}$ of substrate compound used. This procedure was repeated five consecutive times totally under the same conditions. Aliquots of every culture were plated on solidified BHM and sprayed with concentrated substrates used to produce solid films on the Petri dishes. The aromatic degrading candidates were identified by the presence of clearing zones around the colonies that indicates substrate utilization. The isolates were identified and named based on morphological, physiological and biochemical characteristics presented in Bergey's Manual of Determinative Bacteriology (Holt et al., 1994) and the APi Kit profiling (Api, bioMerieux, France, 2009). Subsequently, bacterial growth is monitored by taking the absorbance at $595 \mathrm{~nm}$.

\section{Cultures and growth rates}

Inocula were pregrown in $10 \mathrm{ml}$ nutrient broth medium for $12 \mathrm{~h}$. Cells were grown aerobically in $50 \mathrm{ml}$ Erlenmeyer flasks. Flasks were filled to no more than $20 \%$ capacity. All growth rates were determined with cells growing at $30^{\circ} \mathrm{C}$ in an incubator shaker at 150 rpm. The absorbency of the culture was measured at approximately $4 \mathrm{~h}$ intervals for three days with a spectrophotometer at 595 nm. Cultures were usually harvested at absorbency 0.660 . Cell numbers were no longer linear with respect to absorbency above this value. Also, $\mathrm{pH}$ of the medium should not change when experiments were terminated at this absorbency. Cells were harvested by centrifugation for $5 \mathrm{~min}$ at 3,000 $\mathrm{x} \mathrm{g}$ at room temperature (Krieg, 1984).

Media were used are LB (Trypton, 10g; yeast extract, $5 \mathrm{~g} ; \mathrm{NaCl}, 5 \mathrm{~g}$; distilled water, 1000 
$\mathrm{ml}$ ) and other strains were grown at $30^{\circ} \mathrm{C}$. Basal salt medium (BSM) consisting of: $\mathrm{K}_{2} \mathrm{HPO}_{4}(4 \mathrm{~g}) ; \mathrm{Na}_{2} \mathrm{HPO}_{4}(4 \mathrm{~g}) ; \mathrm{NH}_{4} \mathrm{Cl}(2 \mathrm{~g})$; $\mathrm{MgCl}_{2} \cdot 6 \mathrm{H}_{2} \mathrm{O}(0.2 \mathrm{~g}) ; \mathrm{CaCl}_{2} \cdot 2 \mathrm{H}_{2} \mathrm{O}(0.001 \mathrm{~g})$ and $\mathrm{FeCl}_{3} \cdot 6 \mathrm{H}_{2} \mathrm{O}(0.001 \mathrm{~g})$ per liter of distilled, deionized water $\mathrm{pH} 7.0$ was used for isolation and growth of the microorganisms under sulfur deficient conditions (Kilbaneet al., 1990). Glycerol (20 mM) was used as the carbon source and was omitted when other test compounds were used instead. Soil samples and subsequently isolated strains were inoculated in BSM supplemented with crude oil or oil products $(200 \mathrm{~g} / \mathrm{L})$ as well as $0.5 \mathrm{mMdibenzothiophene}$ (DBT) or dibenzothiophenesulfone $\left(\mathrm{DBTO}_{2}\right)$ or $0.2 \mathrm{mM}$ of $\mathrm{MgSO}_{4}$. The sulfur sources were added to the medium from sterile stock solutions before inoculation $\left(10 \mathrm{mM}\right.$ DBT or $\mathrm{DBTO}_{2}$ in ethanol; $50 \mathrm{mM} \mathrm{MgSO}_{4}$ in deionized water. Media were designated as DBT, $\mathrm{DBTO}_{2}$, or $\mathrm{MgSO}_{4}$ medium, respectively (Wang and Krawiec1994). BSM solidified with $15 \mathrm{~g}$ of agar per liter was used for isolating bacterial colonies. All cultures were incubated at $30^{\circ} \mathrm{C}$ and liquid cultures were shaken at $200 \mathrm{rpm}$.

Microbial and biochemical techniques were employed in this project. The effects of $\mathrm{pH}$, temperature degrees on crude oil and oil products biodesulfurization and growth rates of some isolates were determined. The growth rates of cultures in exponential phase were determine from linear regressions of $\log _{10}$ absorbency vs. time, calculating a least squares fit of data from the exponential growth phase, and determining the slope of this line. The instantaneous growth rate $(\mu)$ will be determined from the slope of this line $\mathrm{x} \ln _{10} ; \mu$ had the dimensions/h (Koch, 1984).

\section{Optical density and biomass measurements}

The turbidity of the cultures was determined by measuring the Optical Density (OD) at a wavelength of $595 \mathrm{~nm}$ in $2 \mathrm{ml}$ cuvettes using a spectrophotometer (Biophotometer plus, Eppendorf). The net dry weight for the biomass was determined simultaneously. A 1 $\mathrm{mL}$ of culture was centrifuged at $1500 \mathrm{rpm}$ for $10 \mathrm{~min}$, washed twice with distilled water, poured into a pre-weighed container, dried overnight at $90{ }^{\circ} \mathrm{C}$ to constant weight and cooled for reweighing. The linear relation between $\mathrm{OD}_{595}$ and dry mass was obtained.

\section{Effect of crude oil and oil products concentrations on sulfur bacteria growth activity}

Growth of the isolated bacterial strains on different concentrations of crude oil, kerosene, benzene, motor oil, diesel oil and DBT was evaluated by measuring culture optical density (OD) at $595 \mathrm{~nm}$.

\section{Procedure for sulfur removal}

The bacteria were used to desulfurize crude oil and/or oil products under three conditions. These include different time duration, temperature and different $\mathrm{pH}$ degrees. The desulfurized crude oil and oil products were subjected to ultra violet visible spectrophotometric analysis.

\section{Quantification of sulfur}

Biodesulfurized crude oil or oil refiners sample $(2 \mathrm{ml})$ was weighed in a conical flask and added to $10 \mathrm{ml}$ of concentrated $\mathrm{HCl}$ contained in Kjedahl digestion flask. Distilled water $(20 \mathrm{ml})$ was then added. The contents were shaken to hydrolyze and then allowed to stay for 3 hours. The content was filtered with No.1 Whatman filter paper. The filtrate was kept for analysis. The filtrate $(5 \mathrm{ml})$ was poured into a test tube. Distilled water $(15 \mathrm{ml})$ and $2 \mathrm{ml}$ of conditioning reagent was then added. The test tube was covered and allowed to stand for few hours. A Spatula full of $\mathrm{BaCl}_{2}$ was then added. The turbidity was read 
with ultra violet visible spectrophotometer. The other compounds were analyzed using gas chromatograph (GC) equipped with a pulsed flame photoatomic detector (PFPD) according to Aribike et al., (2009).

\section{Molecular genetics analysis}

\section{DNA extraction}

The cell pellets form all isolates were used to extract genomic DNA using (Jena Bioscience, Germany) extraction kit according to manufacturer's instructions.

\section{PCR amplification of 16S-rRNA gene}

Primer sequences used to amplify the $16 \mathrm{~S}$ rRNA gene fragment were: U1 [5CCA GCA GCC GCG GTA ATA CG3] and U2 [5ATC GG(C/T) TAC CTT GTT ACG ACT TC3] according to Kumara et al., (2006).The PCR master mix contained10Pmol of each primer and $12.5 \mu \mathrm{l}$ of $2 \mathrm{xSuperHot} \mathrm{PCR} \mathrm{Master} \mathrm{Mix}$ (Bioron, Ludwigshafen, Germany) mixed with 50 to $100 \mathrm{ng}$ of DNA template. Sterile d.H2O was added to a final volume of $25 \mu \mathrm{l}$. Thermal cycler (Uno II, Biometra, Germany) program was $94{ }^{\circ} \mathrm{C}$ for $4 \mathrm{~min} ., 94{ }^{\circ} \mathrm{C}$ for 1 min., $55^{\circ} \mathrm{C}$ for $1 \mathrm{~min} ., 72{ }^{\circ} \mathrm{C}$ for $1.5 \mathrm{~min}$, the number of cycles was 35 cycle and the post $\mathrm{PCR}$ reaction time was $72^{\circ} \mathrm{C}$ for $5 \mathrm{~min}$.

\section{Analysis of the PCR products}

The PCR reaction products were electrophoresed with 100 bp ladder marker (Fermentas, Germany) on 10 x $14 \mathrm{~cm} 1.5 \%$ agarose gel (Bioshop, Canada) for $30 \mathrm{~min}$ using Tris-borate- EDTA Buffer. The gels were stained with $0.5 \mathrm{ug} / \mathrm{ml}$ of ethidium bromide, visualized under the UV light (Watanabe et al., 2001)and documented using a GeneSnap 4.00- Gene Genius Bio Imaging System (Syngene, Frederick, Maryland, USA).

\section{Sequencing of 16S-rRNA gene}

The 990bp PCR-products of each isolate were purified from excess primers and nucleotides by the use of AxyPrep PCR Clean-up kit (AXYGEN Biosciences, Union City, California, USA) and directly sequenced using the same primers as described for the amplification process. The products were sequenced using the Big Dye Terminator Cycle Sequencing Ready Reaction Kit (ABI Applied Biosystems, Foster City, California, USA) on a 3130XL Genetic Analyzer (Applied Biosystems). The bacterial 16SrDNA sequences obtained were then aligned with known 16S-rDNA sequences in Genbank using the basic local alignment search tool (BLAST) at the National Center for Biotechnology Information, and percent homology scores were generated to identify bacteria (Maniatis et al., 1982).

\section{Data analysis}

Data collected were statistically analyzed by using SPSS program package. Tests of significance were done using least square difference test according to Steel and Torrie (1977). All experiments were repeated at least three times.

\section{Results and Discussions}

\section{Prevalence of bacteria in polluted soils}

Sulfur desulfurizing bacteria were estimated in contaminated soil with oil or oil products (Table 1). Sulfur desulfurizing bacteria enumerated on 2 different media shown in table 1. Moisture contents were ranged from $77.3-85.1 \%$ in all collected samples. The total sulfur bacteria were ranged from $1.6 \times 10^{4}$ $2.8 \times 10^{6} \mathrm{CFU}$ gsoil $^{-1}$ on PCA media and $4.1 \times 10^{2}-2.1 \times 10^{6} \mathrm{CFU} \mathrm{g} \mathrm{soil}^{-1}$ on basal media supplemented with DBT. The highest numbers were obtained from Kerosene 
$\left(2.1 \times 10^{6} \mathrm{CFU} \mathrm{g} \mathrm{soil}^{-1}\right)$ and $2 \mathrm{HBP}\left(2.8 \times 10^{6}\right.$ CFU $\mathrm{g} \mathrm{soil}^{-1}$ ) treated samples on PCA media and $2.1 \times 10^{6} \mathrm{CFU} \quad \mathrm{g}$ soil $^{-1}$ from DBT supplemented media. The lowest numbers were obtained from motor oil $\left(0.9 \times 10^{4} \mathrm{CFU}\right.$ $\mathrm{g}$ soil $\left.^{-1}\right)$ and crude oil $\left(1.6 \times 10^{4}\right)$ on PCA media and kerosene $\left(4.1 \times 10^{2} \mathrm{CFU} \mathrm{g} \mathrm{soil}^{-1}\right)$ on DBT supplemented media. Furthermore, numbers of growing desulfurizing bacteria was higher on PCA media than basic media plus DBT. This could be explained by nature of oil or substrate added to contaminated soil. In general, the presence and numbers of sulfur desulfurizing bacteria were various among soil samples (Table 1). No growth was observed on both media for other soil samples contaminated with other oil products heavy crude oils, $3.96 \%$ sulfur (bitumen), and gasoline (Data not shown).

All bacteria showed to be capable of biodesulfurization of oil or oil products, as they were able to grow in PCA media and minimal mineral medium supplemented with DBTor 2HBPas the sole sulfur and carbon source. Therefore, all wiled local bacterial flora grow on both media showed broad specificity for sulfur removal from oil and oil refiners. These growing sulfur desulfurizing bacteria showed broad specificity for sulfur removal whether crude oil, oil products or substrates i.e. DBT or HBP as sole sources of sulfur.

Dibenzothiophene DBT (in hexadecane) was used as model oil to carry out a stable continuous desulfurization (Castorena et al., 2002; Youssef and El-Abyad 2015; Amin, 2011). Almost all of the bacteria reported could degrade DBT to 2-HBP or its derivatives through a sulfur-specific pathway (Castorena et al., 2002; Amin, 2011; Bhatia and Sharma, 2012). These bacteria can be used to lower sulfur levels in oil products. Therefore, isolates showed broad specificity for sulfur removal.

\section{Enrichment and isolation of desulfurizing bacteria}

All twelve isolates under study (labeled from an 'TU- S' series as TU-S1, $-\mathrm{S} 2,-\mathrm{S} 3,-\mathrm{S} 4$, -S5, -S6, -S7, -S8, -S9, -S10, -S11, and S12) (Table 2) showed to be capable of biodesulfurization of oils, as they were able to grow in minimal mineral medium (BSM) supplemented with DBT as the sole sulfur and carbon source. Isolates from various polluted soils were isolated by enrichment culture technique and deposited in our microbial bank at Taif University, Saudi Arabia in our laboratory. The isolates were identified on the basis of their cultural, physiological and biochemical characteristics according to Bergey's Manual of Determinative Bacteriology (9 $9^{\text {th }}$ edition) (Holt et al., 1994) and Api kit profiles (ApiBioMerieuxsa, 2009). Phenotypic examination of the recovered isolates revealed that they belong to the five different genera of Bacillus, Pseudomonas, Rodococcus, Mycobacterium, and Klebsiella (Table 2). Furthermore, more than five isolates were isolated from free contaminated soil with crude oil or oil products. All selected strains showed optimal growth at $35^{\circ} \mathrm{C}$ but grows in two different media. Strains were local wild isolates isolated by enrichment culture technique from oil refinery at Jeddah, and some gas stations at Taif, KSA. Many investigators have been isolated and studied sulfur biodesulfurizing bacteria around the world from oil and oil products of contaminated soil (Anderson and Lovley 2000; López-Cortés et al., 2006; Melnyk et al., 2011; Pfeffer et al., 2012; Srujana Kathi and Khan, 2013).

Identification, morphological, and biochemical characterization of isolate

Isolates from various polluted soils were isolated by enrichment culture technique. Further support to the assignment of these isolates was given by positive results for the 
Gram test, as well as by cells morphology under light microscopy. The twelve isolates were identified on the basis of their cultural, physiological, biochemical characteristics (API profiles) and 16S-rRNA gene sequencing (Table 3). Table (3) showed five isolated biodesulfurizing genera.

These isolates were identified on the basis of their cultural and biochemical characteristics according to Bergey's Manual of Determinative Bacteriology ( $9^{\text {th }}$ edition) (Holt et al., 1994) and Api kit profiles (ApiBioMerieuxsa, 2009). The examination of the recovered isolates revealed that they belong to five different genera: Bacillus, Pseudomonas, Rodococcus, Mycobacterium, and Klebsiella.

The data of 16S-rDNA sequence analysis showed that $16 \mathrm{~S}-\mathrm{rDNA}$ sequence of isolates S1-S12 were 98\% identical to that of Bacillus pumlius, Pseudomonas putida, Pseudomonas stutzeri, Bacillus subtilis, Bacillus pumlius, Rodococcus erythropolis, Rodococcus ruber, Mycobacterium pheli, Mycobacterium pheli, Klebsiella oxytoca, Mycobacterium goodie, Bacillus subtilis, respectively.

All selected strains showed optimal growth at $35^{\circ} \mathrm{C}$ but grows in different media amended with DTB, oil or oil products. Isolates showed to be capable of biodesulfurization of oils or oil products, as they were able to grow in minimal mineral medium supplemented with DBT as the sole sulfur and carbon source.

The natural environment, such as polluted soil or oil field, usually provides the best niches to source microorganisms with potential for BDS activities. As these microorganisms are cultivated and isolated in the laboratory for the purpose of BDS, they display different potentials arising from their different genetic make-ups and conditions that they were previously acclimatized to. For BDS reactions, whole cells or cell extracts can be used. In the case of whole cells, these can be resting cells as well as growing ones (Nuhu 2013). Previously, only Gram bacteria were harnessed for these desulfurization activities (Gunametal, 2006). Elsewhere, the resting cells of Rhodococcus erythropolis SHT87 isolated from oil- contaminated soil in Tehran was found to contain three sulfurmetabolizing genes, namely dszA, dszB and dszC (Davoodi-Dehaghani et al., 2010).

A newly identified Microbacterium sp. NISOC-06 was employed to achieve close to 95\% desulfurization of $1 \mathrm{mmol} / \mathrm{L}$ DBT during a 2-week incubation period (Papizadeh etal.2010). Apart from BTH, Mycobacterium phlei WU-0103 can also utilize another heterocyclic sulfur-containing compound, naphtha $[2,1-\mathrm{b}] \mathrm{TH}$, and $52 \%$ reduction in sulfur content of a 12-fold diluted crude straight-run light gas oil fraction was accomplished (Ishii et al., 2005).

While equal percent reduction in TSC of Liaoning Crude oil (from 3,600 to $1,478 \mathrm{mg} / \mathrm{L})$ was achieved in a longer period of time (72h), 99\%reduction in total sulfur level of DBT in tetradecane was accomplished, under controlled $\mathrm{pH}$ and temperature, by the thermiphilic bacterium, Mycobacterium goodie X7B (Li et al., 2007). Other, biodesulfurizing bacteria were isolated and identified $P$. stutzeri (Dinamarca et al., 2010), P. putida (Alcon et al., 2005), R. erythropolis (Ansari et al., 2009), Mycobacterium sp. (Chen, 2008), Bacillus subtilis (Kirimura et al., 2001; Ohshiro et al., 2005; Al-Bahry et al., 2016) and Klebsiella sp. 13T (Bhatia and Sharma, 2012). 
Table.1 Enumeration of desulfurizing bacteria in different contaminated soil samples polluted with oil and oil products

\begin{tabular}{|l|c|l|l|}
\hline \multirow{2}{*}{ Sample $^{+}$} & \multicolumn{3}{|c|}{ Media } \\
\cline { 2 - 4 } & Moisture \% & \multicolumn{1}{|c|}{ PCA $^{*}$} & BSM+DBT $^{* *}$ \\
\hline Crude oil & 79.3 & $1.6 \times 10^{4}$ & $1.6 \times 10^{4}$ \\
\hline Diesel oil & 85.1 & $2.31 \times 10^{5}$ & $3.9 \times 10^{3}$ \\
\hline Kerosene oil & 81.2 & $2.1 \times 10^{6}$ & $4.1 \times 10^{2}$ \\
\hline Benzene oil & 80.1 & $1.1 \times 10^{5}$ & $1.1 \times 10^{6}$ \\
\hline Motor oil & 77.3 & $0.9 \times 10^{4}$ & $1.5 \times 10^{5}$ \\
\hline DBT treated & 82.5 & $1.7 \times 10^{5}$ & $2.1 \times 10^{6}$ \\
\hline 2HBP treated & 83.2 & $2.8 \times 10^{6}$ & $1.4 \times 10^{4}$ \\
\hline
\end{tabular}

+ , Each sample is an average of 3 mixed samples. *, Stilinovi andHrenovic(2009); **, Kilbane et al., (1990)

Table.2 Morphology, physiology, and growth of five selected biodesulfurizing bacteria

\begin{tabular}{|l|l|l|l|l|c|}
\hline Identification Code & TU-S2 & TU-S5 & TU-S7 & TU-S10 & TU-S12 \\
\hline Proposed Name & $\begin{array}{l}\text { Pseudomonas } \\
\text { putida }\end{array}$ & $\begin{array}{l}\text { Bacillus } \\
\text { pumils }\end{array}$ & $\begin{array}{l}\text { Rodococcus } \\
\text { erythropolis }\end{array}$ & $\begin{array}{l}\text { Klebsiella } \\
\text { oxytoca }\end{array}$ & $\begin{array}{l}\text { Bacillus } \\
\text { subtilis }\end{array}$ \\
\hline Colony color & Yellowish & Creamy & white & Clear & Creamy \\
\hline Morphology & Short rods & Bacilli & Filaments & Short rods & Bacilli \\
\hline Gram Stain & - & + & + & - & + \\
\hline Motility & + & + & - & + & + \\
\hline Oxidase reaction & + & + & + & - & + \\
\hline Catalase reaction & + & + & + & + & + \\
\hline
\end{tabular}

Table.3 Identification of selected local wild isolated bacteria and designated codes

\begin{tabular}{|l|l|l|}
\hline Number & Identification & Lab code \\
\hline 1 & Bacillus pumilus & TU-S1 \\
\hline 2 & Pseudomonas putida & TU-S2 \\
\hline 3 & Pseudomonas stutzeri & TU-S3 \\
\hline 4 & Bacillus subtilis & TU-S4 \\
\hline 5 & Bacillus pumilus & TU-S5 \\
\hline 6 & Rodococcus erythropolis & TU-S6 \\
\hline 7 & Rodococcus ruber & TU-S7 \\
\hline 8 & Mycobacterium pheli & TU-S8 \\
\hline 9 & Mycobacterium pheli & TU-S9 \\
\hline 10 & Klebsiella oxytoca & TU-S10 \\
\hline 11 & Mycobacterium goodii & TU-S11 \\
\hline 12 & Bacillus subtilis & TU-S12 \\
\hline
\end{tabular}


Table.4 Specific growth rate and optical density of selected isolated strains on oil and oil refineries (benzene, kerosene and diesel)

\begin{tabular}{|l|l|l|l|l|c|c|c|c|}
\hline \multirow{2}{*}{ Isolates } & \multicolumn{4}{|c|}{ Growth rate (h-1) } & \multicolumn{4}{c|}{ O.D. } \\
\cline { 2 - 10 } & Oil & Diesel & Kerosene & Benzene & Oil & Diesel & Kerosene & Benzene \\
\hline TU-S2 & 0.0342 & 0.0273 & 0.0142 & 0.0042 & 49 & 37 & 39 & 46 \\
\hline TU -S5 & 0.0437 & 0.1365 & 0.0232 & 0.0342 & 63 & 56 & 41 & 55 \\
\hline TU -S6 & 0.0351 & 0.2430 & 0.0311 & 0.0352 & 70 & 46 & 46 & 37 \\
\hline TU -S9 & 0.0241 & 0.0362 & 0.0351 & 0.0441 & 57 & 43 & 56 & 46 \\
\hline TU -S 10 & 0.0231 & 0.1621 & 0.0342 & 0.0243 & 46 & 48 & 53 & 39 \\
\hline TU -S12 & 0.0343 & 0.0461 & 0.0243 & 0.0342 & 67 & 55 & 47 & 43 \\
\hline
\end{tabular}

Table.5 Performance of selected local isolates of desulfurization of oil and oil products ${ }^{\mathrm{a}}$

\begin{tabular}{|c|c|c|c|c|c|}
\hline \multirow[t]{2}{*}{ Isolate } & \multicolumn{5}{|c|}{ Sulfur removed $\%^{b}$} \\
\hline & Crude oil & Diesel & Kerosene & $\overline{\text { Benzene }}$ & Motor oil \\
\hline TU-S2 & 31.0 & 21.1 & 33.2 & 21.2 & 21.6 \\
\hline TU-S5 & 25.0 & 19.3 & 31.0 & 25.0 & 29.0 \\
\hline TU-S6 & 26.1 & 20.1 & 29.0 & 27.0 & 29.0 \\
\hline TU-S9 & 23.2 & 15.4 & 32.0 & 26.1 & 30.3 \\
\hline TU-S10 & 24.3 & 21.0 & 19.0 & 19.3 & 18.4 \\
\hline TU-S12 & 19.3 & 20.0 & 22.0 & 17.2 & 21.2 \\
\hline
\end{tabular}

${ }^{\mathrm{a}}=$ All experiments were carried out according to the details in Materials and Methods section, $\mathrm{b}=$ Each value represents the average value obtained from triplicate flasks.

Table.6 Comparative performance of selected local isolates and commercial strains of desulfurization of oil and oil products ${ }^{a}$

\begin{tabular}{|c|c|c|c|c|c|c|}
\hline Strain* & \multicolumn{6}{|c|}{${\text { Sulfur removed } \%^{b}}^{b}$} \\
\hline Local & & & & & & \\
\hline P. putidaTU-S2 & 31.0 & 21.1 & 33.2 & 21.2 & 21.6 & 37.6 \\
\hline B. pumilus TU-S5 & 25.0 & 19.3 & 31.0 & 25.0 & 29.0 & 33.2 \\
\hline R. erythropolis TU-S7 & 26.1 & 20.1 & 29.0 & 27.0 & 29.0 & 34.5 \\
\hline \multicolumn{7}{|l|}{ Commercial } \\
\hline R. erythropolis & 23.2 & 15.4 & 32.0 & 26.1 & 30.3 & 29.4 \\
\hline Desulfobacteriumanaline & 24.3 & 21.0 & 19.0 & 19.3 & 18.4 & 30.1 \\
\hline Thiobacillusthiooxidances & 19.3 & 20.0 & 22.0 & 17.2 & 21.2 & 23.2 \\
\hline
\end{tabular}


Table 3 shows morphological, physiological and biochemical characteristics of selected isolates. Strains were local isolates isolated by enrichment technique. Colony morphology on nutrient agar plate, S12showed creamy, big spreading, finely wrinkled and slimy. In S2showed yellowish, small, opaque irregular colonies with earthy odors, S7 was medium white colony with gray center, and S10 was small clear colony (Table 3 ). In blood agar plates showed the hemolysis. Phenotypic examination of the recovered microorganisms revealed that they belong to the genera of Bacillus, Rodococcus, Klebsiella and Pseudomonas (Table 3). Five isolates Pseudomonas putida S2, Bacillus subtilis S12, Bacillus pumils S5, Rodococcus ruber S7, Klebsiella oxytoca S10 showed good growth on Bushnell- Haas medium amended with crude oil as a sole carbon source and were selected based on the growth and degradation ability. All selected strains showed optimal growth at $35^{\circ} \mathrm{C}$.

\section{Growth kinetics}

All selected isolates grow on petroleum oil and oil products (Table 4). Isolate S5, S6 and S9 showed best growth on crude oil, diesel, kerosene and benzene, respectively, except $S 9$ showed best growth on both kerosene and benzene only (Table 4). Isolate S10 and S12 showed the lowest growth rate on examined oil and oil products. Also, Isolate S6 showed highest optical density on crude oil, and isolate S5 showed good optical density on both diesel and benzene. Isolate S5 and S9 showed best optical density (56) on diesel and kerosene, respectively.

In general, microorganisms produce biosurfactants to increase their interfacial area for contact to give improved uptake of hydrophobic substrates. However, it has been observed that the exopolymers synthesized by these strains in media with glucose as carbon and energy source, had a remarkable capacity of emulsifying hydrocarbon compounds (Martinez-Checa et al., 2002).

Biodesulfurization of oil and oil products by bacteria: The results obtained with crude oil and oil products removal by 6 selected isolated strains (Table 5) indicated that the concentration of sulfur decreases after 4 days of incubation in all treatment by different isolates. Isolate $\mathrm{S} 2$ ( $P$. putida) removed the highest amount of kerosene (33.2\%) followed by crude oil $(31 \%)$. Also, strain S9 (M. phlei) removed $(32 \%)$ of kerosene (Table 4$)$. Isolate S10 (Klebsiella oxytoca) and S12 (B. subtilis) removed the lowest amount of oil or oil products tested (Table 4). Furthermore, isolate S9 (M. pheli) and S12 (B. subtilis) removed the lowest amount of diesel oil $(15.4 \%)$ and benzene $(17.2 \%)$, respectively (Table 4). Also, the results obtained with DBT removal (0.3 mM DBT) by S2, S6 and S9 indicated that the concentration decreases after 4 days of incubation (data not shown). Our experiment showed a removal of $100 \%$ of sulfur after 8 days of incubation with $0.3 \mathrm{mM}$ DBT concentrations.

Local isolated bacteria had the potential to desulfurize crude oil or oil refiners but with different rates using it as sole sulfur source. Microorganisms, particularly Rhodococcus (Izumi et al., 1994), Bacillus (Kirimura et al., 2000; Buzanello et al., 2014), Pseudomonas (Al-Zahrani and Idris, 2010, Jamshid et al., 2010), Mycobacterium (Ishii et al., 2005), Klebsiella (Bhatia, Sharma, 2012)species have been found to metabolize crude oil and oil products as well as DBT as a source of sulfur by cleaving the $\mathrm{C}-\mathrm{S}$ bond of sulfur compound in crude oil products or DBT via a sulfur-specific pathway (4 S pathway) without affecting the carbon skeleton. Tong et al., (2005) reported that Rodococcus spp desulfurizing organic sulfur of diesel oil by resting cells. Rhodococcus sp. FS-1, which 
can specially break the C-S bond of dibenzothiophene (DBT) and convert DBT into 2-hydrobenzophene by " $4 \mathrm{~S}$ " pathway, is used to decrease the sulfur content in diesel oil and it was strongly high. Also, other results indicated that $M$. phlei WU-0103 may have a good potential as a biocatalyst for practical biodesulfurization of diesel oil. Other microorganisms i.e. Stachybotrys bisbyi TUSb1 formed a compound free of sulfur (biphenyl). The desulfurization and formation of biphenyl was determined by the continuity of culture from 4 to 10 days at $35^{\circ} \mathrm{C}$ in the concentration of $0.3 \mathrm{mM}$ DBT. HPLC results suggest that the final metabolite of dibenzothiophene by Stachybotrys bisbyi TUSb1 is the biphenyl. The final product biphenyl suggests that the metabolic pathway used by Stachybotrys bisbyi TUSb1 in the biodesulfurization process with $0.3 \mathrm{mM}$ of DBT, indicated the specific via of the $4 \mathrm{~S}$ (Gherbawy et al., 2016). The desulfurization of DBT and formation of 2HBP have been detected by many bacteria (Omori et al., 1992).Bacteria tested metabolized a broad range of organic sulfur compounds in crude oils and oil products, suggesting its potential application to the desulfurization of petroleum oil and oil products.

Comparative experiments were carried out to provide information relevant to the biodesulfurizing trait of 3 reference strains and 3 local isolates (Table 6). In general, the rates of removing sulfur from oil or oil refiners by selected local isolates were higher than references strains (ATCC) cultures being the highest was S2 (P. putida) $33.2 \%$ on kerosene and $37.6 \%$ on DBT after $24 \mathrm{hr}$ only of incubation at $35^{\circ} \mathrm{C}$ (Table 5).

However, the relative biodesulfurization rates for commercial strains $R$. erythropolis, $D$. analine and $T$. thiooxidances showed the highest amount of removing sulfur of kerosene $32 \%$ and $30.3 \%$ of motor oil, as well as $30.1 \%$ and $23.2 \%$ of DBT when used as sole sulfur sources, respectively (Table 5). The experiment showed a removal of $100 \%$ after 10 days of incubation with crude oil or oil products and $\mathrm{pH}$ of the culture medium was measured after 7 days (data not shown).

All biodesulfurizing bacteria whether local isolates or standard strains in our experiments were able to desulfurize all crude oil or oil refiners but with different rates using it as sole sulfur source. Strains from the bacterial genus Rhodococcus were most often reported, such as $R$. erythropolis. In literature, a number of other microorganisms, particularly Rhodococcus (Izumi et al., 1994), Bacillus (Kirimura et al., 2000), Buzanello et al., 2014, Pseudomonas (Al-Zahrani and Idris, 2010, Jamshid et al., 2010), Mycobacterium (Ishii et al., 2005), Klebsiella (Bhatia, Sharma. 2012), Arthrobacter (Seo et al., 2006) and Gordonia (Li et al., 2006) species have been found to metabolize crude oil and oil products as well as DBT as a source of sulfur by cleaving the $\mathrm{C}-\mathrm{S}$ bond of sulfur compound in crude oil products or DBT via a sulfur-specific pathway (4S pathway) without affecting the carbon skeleton. These results suggested that hydrodesulfurization (HDS) of crude or oil products through microbial activities has been shown to be a potential alternative to HDS, since HDS cannot remove the heterocyclic organo-sulfur compounds such as dibenzothiophene (DBT) (Sumedha and Sharma, 2010) which represent about $70 \%$ of the sulfur in crude oils. Thermophilic microorganisms are more appropriate to be used for BDS applications following HDS (Bhatia and Sharma, 2012). Further, using local isolates is more reliable and better than imported strains which are more adapted to our environment.

In addition, using a consortium of 3 local isolates, $P$. putida TU-S2, B. pumlius TU-S5, and $R$. erythropolis TU-S7 Removed $90 \%$ of sulfur of crude oil, and refined petroleum products: kerosene, benzene, diesel as well as 
the model compound DBT after 3 days only (data not shown).

The overall low levels of remaining DBT after only $48 \mathrm{~h}$ in culture with the $\sim 100$ times higher starting level of DBT in the media (0.5 $\mathrm{mM}$ ), it seems clear that a fast-consumption metabolism is occurring. In this circumstance, it would be reasonable to expect that stoichiometric high levels of HBP would be found in culture from the use of DBT at the beginning of the $4 \mathrm{~S}$ pathway. However, the relatively low overall levels $(<0.07 \mathrm{mM})$ of HBP detected and the lack of a pattern for its accumulation in the tested media (data not shown) suggest that most of the HBP produced may have been somehow consumed or degraded after its synthesis. Furthermore, during its growth, high levels of DBT were removed in the first 24 hours, and a rapid DBT degradation within the first hour of incubation was observed. Detection of 2hydroxybiphenyl (HBP), a marker for the $4 \mathrm{~S}$ pathway, suggests strains have metabolical capability for DBT desulfurization. The presence of $\mathrm{MgSO}_{4}$ in growth medium as an additional sulfur source has interfered with DBT degradation. Although the HBP detection data would also indicate that genes related to this metabolism (such as $d s z \mathrm{C}$ and $d s z \mathrm{~B})$ should be operational, homologous sequences for these genes were lacking, which suggest the existence of a specific mechanism and genes not yet described for DBT consumption/HBP formation in the $B$. pumilus and other isolates (Buzanello et al., 2014). To account for the lack of stoichiometric relationship between DBT and HBP, the existence of another DBTconsumption metabolism that includes the destruction of the molecule ring cannot be discarded. Further research involving biochemical/molecular tests and full-genome sequencing is currently underway to address this question in more details.
It is concluded to the best of our knowledge, this is might be the first report of the identification of five different genera as a sulfur removing bacteria in Saudi Arabia. Most organisms cannot efficiently desulfurize crude oil, oil products and both BTs and DBTs which are present in hydrodesulfurized petroleum oil. In our study, all isolates were employed as catalyst for the biodesulfurization of hydrodesulfurized oil products. Bacteria isolated and commercial strains could break the $\mathrm{C}-\mathrm{S}$ bond of DBT and converting it into 2-hydrobenzophene (2HBP) by the " $4 \mathrm{~S}$ ', pathway. The desulfurization results indicated that the mixed bacteria could efficiently desulfurize most of the heterocyclic sulfur compounds in the hydrodesulfurized oil refiners (data not shown). Therefore, our strains showed broad specificity for sulfur removal and a further investigation is highly recommended. The results revealed the possibility to use these bacteria as for the reduction of sulfur content in petroleum oil where they cause pollution problems. Furthermore, results indicated that using a microbial consortium might have a promising application in petroleum oil technology and could be potentially used in microbial enhanced oil recovery (MEOR).

\section{Recommendations}

In order for biodesulfurization to realize commercial success, a variety of process considerations must be addressed including reaction rate, emulsion formation and breakage, biocatalyst recovery, and both gas and liquid mass transport. Biodesulfurization offers an attractive alternative to conventional hydrodesulfurization due to the mild operating conditions and reaction specificity afforded by the biocatalyst. Worldwide, it has been realized that pollution prevention is more economical and socially responsible than clean up, and inevitably the demand for waste site remediation technologies will 
abate. Before such perceived advances can be realized, however, a fundamental knowledge database of sulfur bacteria performance under complex environmental parameters must be attained. This can only be achieved through careful studies and a comparative life cycle assessment that balances risk with biotechnological benefit.

\section{Acknowledgement}

The authors are grateful to Department of Academic Affairs and the Scientific Research Deanship, Taif University, K.S.A. for the financial support of this work.

\section{References}

Abou-Shanab R AI 2007. Characterization and $16 \mathrm{~S}$ rDNA identification of thermotolerant bacteria isolated from hot springs. J.App. Sci. Res, 3(10): 994-1000.

Agarwal P, DKSharma 2010.Comparative studies on the bio- desulfurization of crude oil with other desulfurization techniques and deep desulfurization through integrated processes. Energy Fuels 24:518-524.

Al-Bahry, YM Al-Wahaibi, B Al-Hinai, SJ Joshi, AE Elshafie, AS Al-Bemani, J AlSabahi. 2016. Potential in heavy oil biodegradation via enrichment of spore forming bacterial consortia. J Petrol Explor Prod Technol. 6(4): 787-799. Doi: 10.1007/s13202-016-0228-8.

Alcon A, VE Santos, AB Martin, P Yustos, F Garcia-Ochoa 2005.Biodesulfurisation of DBT with Pseudomonas putida CECT5279byrestingcells:influenceofcellg rowth time on reducing equivalent concentration and $\mathrm{HpaC}$ activity. BiochemEng J26:168-175.

Al-Zahrani AA, GMA Idris. 2010. Biological Treatment of Hydrocarbon contaminants: Petroleum Hydrocarbon uptake by Pseudomonas alkanolytica, JKAU: Eng. Sci., Vol. 21(1): 39-53 (1431A.H./2010 A.D.). doi: 10.4197 / Eng. 21-1.3
Amin GA 2011.Integrated Two-Stage Process for Biodesulfurization of Model Oil by Vertical Rotating Immobilized Cell Reactor with the Bacterium Rhodococcus erythropolis. J Pet Environ Biotechnol 2:107. doi:10.4172/2157-7463.1000107

Amouric A, M Quemeneur, V Grossi, PP Liebgott, R Auria, L Casalot. 2010. Identification of different alkane hydroxylase systems in Rhodococcus ruber strain SP2B, an hexane-degrading actinomycete. Journal of Applied Microbiology. 108, 1903-1916.

Anderson RT, DR Lovley. 2000. Anaerobic bioremediation of ben- zene under sulfate-reducing conditions in a petroleum-contaminated aquifer. Environ.Sci.Technol. 34,2261-2266. doi:10.1021/es991211a

Ansari F, P Grigoriev, S Libor, IE Tothill, JJ Ramsden. 2009.DBT degradation enhancement by decorating Rhodococcus erythropolis IGTS8 with magnetic $\mathrm{Fe} 3 \mathrm{O} 4$ nanoparti- cles.BiotechnolBioeng 102:1505-1512

APi (2009). BioMerieuxsa 69280 Marcy I'Etoile, France. http://www. biomerieux. com.

Aribike DS, AASusu, SCU Nwachukwu, SA Kareem. 2009. Microbial Desulfurization of Diesel by Desulfobacterium aniline. Academia Arena,1(4):

Attomi, Asma. 2007. Microbial treatment of waxy crude oils for mitigation of wax precipitation. J. Petrol. Scien.Engin.55 (12): 111-121

Banat. M., Samarh, N., Murad, M., Horne, R. and Banerjee, S. (1991). 2000 Baker GC, JJ Smith, DA Cowan. 2003. Review and re-analysis of domain-specific $16 \mathrm{~S}$ primers. J Microbiol Methods 55: 541555. doi: 10.1016/j.mimet.2003.08.009

Banat I M, N Samarah, M Murad, R. Horne, S Banerjee. 1991. Biosurfactent production and use in oil tank clean-up. Wld. J. Microbiol.Biotech. 7:80-88.

Banat IM, RS Makkar,.SS Cameortra.1999. Potential commercial applications of 
microbial surfactants. ApplMicrobiol Biotechnol.53:495- 508.

Bayoumi RA, Awad NS, Ibrahim MMM (2010). Molecular genetic characterization of some Biosurfactant producing bacteria isolated from Egyptian red sea mangrove forests. Arab J. Biotech., 13(2):209-222.

Bhatia S, DK Sharma 2012. Thermophilic desulfurization of dibenzothiophene and different petroleum oils by Klebsiella sp. 13T. Environ SciPollut Res. 19: 34913497. DOI 10.1007/s11356-012-0884-2.

Bhatia S, DK Sharma. 2012. Thermophilic desulfurization of dibenzothiophene and different petroleum oils by Klebsiella sp. 13T. Environ SciPollut Res, 19: 34913497. DOI 10.1007/s11356-012-0884-2.

Bo YuXu P, Q Shi, C Ma. 2006. Deep Desulfurization of Diesel Oil and crude oils by a Newly Isolated Rhodococcus erythropolis Strain. Appl Environ Microbiol. 72(1): 54-58. doi: 10.1128/AEM.72.1.54-58.2006.

Buzanello EB, RP Rezende,FMO Sousa, EdeLS Marques, LL Loguercio. 2014. A novel Bacillus pumilus-related strain from tropical landfarm soil is capable of rapid dibenzothiophene degradation and biodesulfurization.BMC Microbiol.14: 257.doi: 10.1186/s12866-014-0257-8.

Castorena G, C Suárez, I Valdez, G Amador, L Fernández and S. Le Borgne2002.Sulfurselective desulfurization of dibenzothiophene and diesel oil by newly isolated Rhodococcus sp. Strains. FEMS Microbiology Letters.215 (1): 157-161

Chen H, W-J Zhang, J-M Chen, Y-B Cai, W Li. 2008. Desulfurization of various organic sulphur compounds and the mixture of DBT? 4,6-DMDBT by Mycobacterium sp. ZD-19. Bioresour Technol 99:36303634

Davoodi-Dehaghani F, Vosoughi M, Ziaee AA (2010) Biode- sulfurization of dibenzothiophene by a newly isolated Rhodococcus erythropolisstrain. BioresourTechnol 101: 1102-1105.
Dinamarca MA, C Ibacache-Quiroga, P Baeza, S Galvez, M Vil-larroel, P Olivero, Ojeda J 2010. Biodesulfurization of gas oil using inorganic supports biomodified with meta- bolically active cell simmobilized by adsorption. Bioresour Technol, 101: 2375-2378. doi:10.1080/01490451.2015.1074320

Gherbawy Y, B El-Deeb, Amal Al Hazzani, Amena Maher, AfafShehata. 2016. Samples and Their Abilities for Dibenzothiophene Desulfurization Mycobiota of Oil-Contaminated Soil. Geomicrobiology J. 33(7): 618-624

GunamIBW,Y Yaku,M Hirano,K Yamamura,F Tomita,T Sone,K Asano.2006. Biodesulfurization of alkylated forms of dibenzothiophene and benzothiophene by Sphingomonas subarctica T7b. J BiosciEng101:322-327.

Guo-QiangLi,Shan-Shan Li, Shi-Wei Qu, QingKun Liu, Ting Ma, Lin Zhu,Feng-Lai Liang, Ru-Lin Liu. 2008. Improved biodesulfurization of hydrodesulfurized diesel oil using Rhodococcus erythropolis and Gordonia sp. Biotechnol Lett. 30: 1759-1764.

Gurtler V, VA Stanisich 1996. New approaches to typing and identification of bacteria using the $16 \mathrm{~S}-23 \mathrm{~S}$ rDNA spacer region. Microbiology, 142:3-16.

Hilyard EJ, MJM Joanne, JS Barry, TH Russell. 2008. Enrichment, isolation and phylogenetic identification of polycyclic aromatic hydrocarbon-degrading bacteria from Elizabeth river sediments. Applied Environmental Microbiology. 74. 11761182.

Holliger C, S Gaspard, G Glod, C Heijman, W Schumacher, RP Schwarzenbach, F Vazquez. 1997. Contaminated environments in the subsurface and bioremediation: organic contaminants. FEMS Microbiol Rev. 20(3-4):517-23.

HolligerC, S Gaspard, G Glod, C Heijman, W Schumacher, R P Schwarzenbach, and F Vazquez, "Contaminated environments in the subsurface and bioremediation: organic contaminants," FEMS 
Microbiology Reviews, vol. 20, no. 3-4, pp. 517-523, 1997. View at Publisher . View at Google Scholar . View at Scopus Holt, John G., Krieg, Noel R., Senath, Peter H. A., Staley, James T., Williams, Stanley T., (eds.). (1994). Bergey's Manual of Determinative Bacteriology, $9^{\text {th }}$ edition. Baltimore: Williams and Wilkins.

Holtman MA, DY Kobayashi. 1997. Identification of Rhodococcus erythropolis isolates capable of degrading the fungicide carbendazim. ApplMicrobiolBiotechnol 47: 578-582. doi: 10.1007/s002530050976.

Ishii Y, S Kozaki, T Furuya, K Kino, K Kirimura. 2005. Thermophilic Biodesulfurization of Various Heterocyclic Sulfur Compounds and Crude Straight-Run Light Gas Oil Fraction by a Newly Isolated Strain Mycobacterium phlei WU-0103. CurrMicrobiol. 50: 63-70. DOI: 10.1007/s00284-004-4403-7

Izumi $\mathrm{Y}, \mathrm{T}$ Oshiro, $\mathrm{H}$ Ogino, $\mathrm{Y}$ Hine, $\mathrm{M}$ Shimao. 1994. Selective desulfurization of dibenzothiophene by R. erythropolis D-1.Appl Environ Microbiol 60: 223226.

Jamshid R, H Javad, M Babak.2010. Increasing of Biodesulfurization Activity of Newly Recombinant Pseudomonas Aeruginosa ATCC 9027 by Cloning the Flavin Reductase Gene. Inter J BiotechnolBiochem 6: 219-229.

Javadli R, A de Klerk. 2012. Desulfurization of heavy oil. Appl Petrochemical Research, 1(1):3-19

Kathi S, AB Khan. 2013. Enrichment, Isolation and Identification of Polycyclic Aromatic Hydrocarbon Degrading Rhodococcus ruber from Sediments. Intern J Scient Research Publications, 3, (2): 1-7.

Kaufman EN, JB Harkins, AP Borole. 1998. Comparison of batch-stirred and electrospray reactors for biodesulfurization of dibenzothiophene in crude oil and hydrocarbon feedstocks. Appl Biochem Biotechnol 73:127144CrossRef
Kilbane II J J. 1990.Sulfur-specific microbial metabolism of organic compounds. Resour. onserv. Recyc.3: 69- 79.

Kilbane J, S Le Borgne. 2004. Petroleum biorefining: the selective removal of sulfur, nitrogen metals. In Petroleum Biotechnology, Developments and perspectives, R. Vazquez-Duhalt and R. Quintero-Ramirez (eds). The Netherlands: Elesevier pp29-65.

Kirimura K, T Furuya, Y Nishii, Y Ishii, K Kino et al., 2000. Biodesulfurization of dibenzothiophene and its derivatives through selective cleavage of carbonsulfur bonds by a moderately thermophilic bacterium B. subtilis WUS2B. J BiosciBioeng 91: 262-266.

Kirimura K, T Furuya, Y Nishii, Y Ishii, K Kino, S Usami.2001. Biodesulfurization of dibenzothiophene and its derivatives through the selective cleavage of carbonsulfur bonds by a moderately thermophilic bacterium Bacillus subtilisWU-S2B. J Biosci Bioeng 91: 262-266.

Kiyohara H, K Nagao, K Yana, 1982. Rapid screen for bacteria degrading water insoluble, solid hydrocarbons on agar plates. Applied Environmental Microbiology. 43, 454-457.

Krieg, NR. 1984. Systematics, P 407-409. In: P. Gerhardt, R.G.E. Murray, R.N. Costllow, E.W. Nester, and W.A.Wood (eds.), Manual of Methods for General Bacteriology. American Society for Microbiology, Washington, DC, USA.

Kumara Mb, Leona V, Materanoa A, Ilzinsa O, Galindo-CastroaI, Fuenmayora S (2006). Polycyclic Aromatic Hydrocarbon Degradation by Biosurfactant-Producing Pseudomonas sp. IR1.Verlag der ZeitschriftfürNaturforschung, Tübingen 203- 012.

Kvenvolden KA, CK Cooper, "Natural seepage of crude oil into the marine environment," Geo-Marine Letters, vol. 23, no. 3-4, pp. 140-146, 2003. View at Publisher . View at Google Scholar · View at Scopus 
Li F, Z Zhang, J Feng, X Cai, P Xu 2007. Biodesulfurization of DBT in tetradecane and crude oil by a facultative thermophilic bacterium Mycobacterium goodii X7B. J Bio- technol 127:222-228.

Li W, M Wang, H Chen, J Chen, Y Shi 2006.Biodesulfurization of dibenzothiophene by growing cells of Gordonia sp. in batch cultures. Biotechnol Lett 28: 1175-1179.

Li W, YZhang, MDWang, Y Shi. 2005. Biodesulfurization of dibenzothiophene and other organic sulfur compounds by a newly isolated Microbacterium strain ZDM2.

doi: http://dx.doi.org/10.1016/j.femsle.2005.0 4.02545-50

Linguist LK, MA Pacheco. 1999. Enzymebased diesel desulfurization process offers energy, $\mathrm{CO}_{2}$ advantages. Oil Gas J 97(8):45-48

López-Cortés A, M-L Fardeau, G Fauque, C Joulian, B Ollivier2006. Reclassification of the sulfate- and nitrate-reducing bacterium Desulfovibrio vulgaris subsp. oxamicus as Desulfovibrio oxamicus sp. nov., comb. nov. Int. J. Syst. Evol.Microbiol.56,14951499.doi:10.1099/ijs.0.64074-0

Maniatis T, EF Fritsch, JSambrook 1982. Molecular Coloning: A laboratory manual. Cold Spring Harbor, N.Y., Cold Spring Harbor Laboratory.

Mehran S, BAmarjeet, M Argyrios 2007. Biodesulfurization of refractory organic sulphur compounds in fossil fuels. BiotechnolAdv 25:570-596.

Melnyk RA, AEngelbrektson, IC Clark, HK Carlson, K Byrne-Bailey, JD Coates. 2011. Identification of a perchlorate reduction genomic islandwithnovelregulatoryandmetabolicge nes.Appl.Environ.Microbiol.77, 74017404. doi:10.1128/AEM.05758-11.

Millar BC, J Xu, JE Moore 2007.Molecular diagnostics of medically important bacterial infections. Curr Issues Mol Biol. 9(1):21-39.
Monticello DJ, W R Finnerty. 1985. Microbial Desulfurization of Fossil Fuels

Monticello DJ.1998. Riding the fossil fuel biodesulfurization wave. Chemtech 28: $38-45$.

Noor, F.D., Suhaimi, A.T., Kalavathy, R., Yin Chun-Yang, 2009.Identification of bacterial strains capable of degrading Malaysian petroleum sludge. Conference on scientific and social research Melaka, Malaysia

NuhuAA. 2013. Bio-catalytic desulfurization of fossil fuels: a mini review. Rev Environ SciBiotechnol 12: 9-23.

Ohshiro T, Ishii Y, Matsubara T, Ueda K, Izumi Y, Kino K, Kirimura K 2005. Dibenzothiophene desulfurizing enzymes from moderately thermophilic bacterium Bacillus subtilis WU-S2B: purification, characterization and over- expression. $\mathbf{J}$ BiosciBioeng100:266-273

Omori T, L Monna, Y Saiki, T Kodama 1992. Desulfurization of Dibenzothiophene by Corynebacterium sp. Strain SYl. Appl Environ Microbiol 58:911-915.

Pacheco MA, EA Lange, PT Pienkos, LQ Yu, MP Rouse, Q Lin, LK Linguist 1999. Recent advances in biodesulfurization of diesel fuel. In: NPRA AM-99-27, 1999, National Petrochemical and Refiners Association, Annual Meeting, 21-23 March, San Antonio, Texas, pp 1-26

Papizadeh M, MR Ardakani, G Ebrahimipour, $\mathrm{H}$ Motamedi 2010.Utilization of dibenzothiophene as sulfur source by Microbacterium sp. NISOC-06. World J Microbiol Bio- technol 26:1195-1200.

Pfeffer, C., S Larsen, J Song, M Dong, FBesenbacher, RL Meyer, et al. 2012. Filamentousbacteriatransportelectronsove rcentimeterdistances.Nature491, 218-221. doi:10.1038/nature11586.

Seo S, S Keum, K Cho, X Li.2006.Degradation of dibenzothiophene and carbazole by Arthrobacter sp. P1-1.In BiodeterBiodegr 58: 36-43.

SrujanaKathi, Anisa B. Khan. 2013. Enrichment, Isolation and Identification of Polycyclic Aromatic Hydrocarbon 
Degrading Rhodococcus ruber from Sediments. Intern J Scien Res Public. 3 (2): 1-7.

Steel, R.G.D., and J. H. Torrie. 1980. Principles and Procedures of Statistics, $2^{\text {nd }}$, Ed., MaGgraw-Hill Book Co., New York, USA.

Stilinovi B and JHrenovic. 2009. Plate method for counting proteolyticsulphideproducing bacteria. Acta Bot. Croat. 68 (1), 57-66.

Sumedha B, K Sharma. 2010. Biodesulfurization of dibenzothiophene, its alkylated derivatives and crude oil by a newly isolated strain Pantoeaagglomerans D23W3.BiochemEng J 50: 104-109.

Taghi Z S, AM Seyed, K Vahid, AK Fatemeh 2008. Molecular genetic differentiation of avian Escherichia coli by RAPD-PCR. Braz. J. Microbiol. 39:494-497.
Tong MY, T Ma, Q Zhang, FL Liang, RL Liu. 2005. Selectively desulfurizing organic sulfur of diesel oil by resting cells. Huan Jing KeXue. 26(1):24-7.

Wang P, S Krawiec. (1994). Desulfurization of dibenzothiophene to 2-Hydroxybiphenyl by some newly isolated bacterial strains. Arch. Microbiol. 161: 266-71.

Watanabe K, Y Kodama, S Harayama 2001.Design and evalution of PCR primers to amplify bacterial $16 \mathrm{~S}$ ribosomal DNA fragments used for community finger printing. J Microbiol. Meth. 44: 253-262.

Youssef M and A El-Abyad. 2015. Fuel Quality Roadmap For Arab States. Centre for Environment and Development in the Arab Region and Europe (CEDARE). March 2015.

\section{How to cite this article:}

Ahmad F. Shahaby and Khaled. M. Essam El-din. 2017. Desulfurization of Crude Oil and Oil Products by Local Isolated Bacterial Strains. Int.J.Curr.Microbiol.App.Sci. 6(4): 2695-2711. doi: http://dx.doi.org/10.20546/ijcmas.2017.604.314 